\title{
Landslides: Journal of the International Consortium on Landslides
}

\author{
Kyoji Sassa and Željko Arbanas
}

\begin{abstract}
The international journal Landslides: Journal of the International Consortium on Landslides was established in April 2004 as the core project of the International Programme on Landslides and a joint initiative of the International Consortium on Landslides and the United Nations and other global organizations. The aims of Landslides are to promote landslide science, technology, and capacity building, and to strengthen global cooperation for landslide risk reduction within the United Nations International Strategy for Disaster Risk Reduction (ISDR). The importance of landslide occurrences, as a one of the main global hazards increasing under global climate change in recent years, focused the scientists, engineers and stakeholders all over the world, especially in regions threatened by landslides, on landslide risk reduction research, with the aim of reducing their consequences. The landslide scientists recognized Landslides as the most important scientific journal in the fields of natural hazards, engineering geology, geotechnics and civil engineering related to any type of landslide research. Results of the most significant landslide research conducted last year were submitted and published in Landslides. The increasing number and quality of published manuscripts in the last years has resulted in a continuous rise of the Landslides journal impact, as expressed by the Thompson Reuters Impact Factor. The Thompson Reuters Impact Factor 2015 is 3.049; ranking No.1 in the category of Engineering, Geological journals. The aims of the Landslides Editorial Board are further improvements of manuscript quality, speed-up of the peer review process and faster publication of landslide science achievements.
\end{abstract}

\section{Keywords}

Landslides • Journal • Science • Impact factor • Publication

K. Sassa

International Consortium on Landslides, 138-1 Tanaka

Asukai-cho, Kyoto, 606-8226, Japan

e-mail: sassa@iclhq.org

Ž. Arbanas $(\bowtie)$

Faculty of Civil Engineering, University of Rijeka, Radmile

Matejčić 3, 51000 Rijeka, Croatia

e-mail: zeljko.arbanas@gradri.uniri.hr

\section{Introduction}

The International Consortium on Landslides (ICL) was established in January 2002 to promote landslide research and capacity building, primarily in developing countries, for the benefit of society and the environment, through the 
establishment of the International Programme on Landslides (IPL) (Sassa 2004). The concept of IPL was developed through discussions at the United Nations World Conference on Disaster Reduction held in Kobe 2005, followed by a roundtable discussion resulting to the 2006 Tokyo Action Plan (Sassa 2006). Landslide research and science have been developed and conducted within the various disciplines and fields of natural, engineering and social sciences outlined in the 2006 Tokyo Action Plan, but until 2004 there was no international journal strictly focused on landslides. The Japan Landslide Society had published an international newsletter, Landslide News, annually from 1987 to 2003 with Kyoji Sassa as chairperson of the publishing committee and editor-in-chief and with the support of Robert L. Schuster as international chief editor (Sassa et al. 2009).

At the first session of the Board of Representatives of ICL, held at the UNESCO Headquarters in Paris, 19-21 November 2002, Kyoji Sassa proposed Landslides: Journal of the International Consortium on Landslides, as the core project of the IPL which was approved as the first IPL coordinating project (IPL-C100) (Sassa et al. 2009). The proposal included development of the international newsletter Landslide News into an international journal on landslides published in full color, with no color-print charges for authors. After negotiation with several international publishers for publication of a full-color scientific journal, agreement was reached with Springer in 2003. Until Landslides, there was no full-color scientific journal in the world (Sassa et al. 2009). Figure 1 is a cover of Landslides 2016. The design has remained the same from the foundation issue of the Journal in April 2004.

The first issue of Landslides: Journal of the International Consortium on Landslides was published in April 2004 and appeared in journal citations of Thomson Reuters (Institute for Scientific Information, ISI) in 2005. The first Thomson Reuters ISI Web of Knowledge Impact Factor, released in 2008, was 0.986. After 2008 Landslides has been recognized by landslide scientists, researchers, professional engineers, international organizations, national and regional governments and other stakeholders as a high-quality specialized journal related to the scientific, technical, social and all other aspects of landside investigation and remediation in the frame of landslide risk reduction. The number of submitted and published manuscripts has continuously increased, providing Landslides' readers better and better insight into all aspects of landslide research around the world. The rate of manuscripts accepted for publishing is almost the same from the first volume until today, ensuring the established quality level of the journal, with the consequent continuous rise of the quality indicators and impact on the scientific community expressed in its Thomson Reuters ISI Web of Knowledge impact factor, which reached

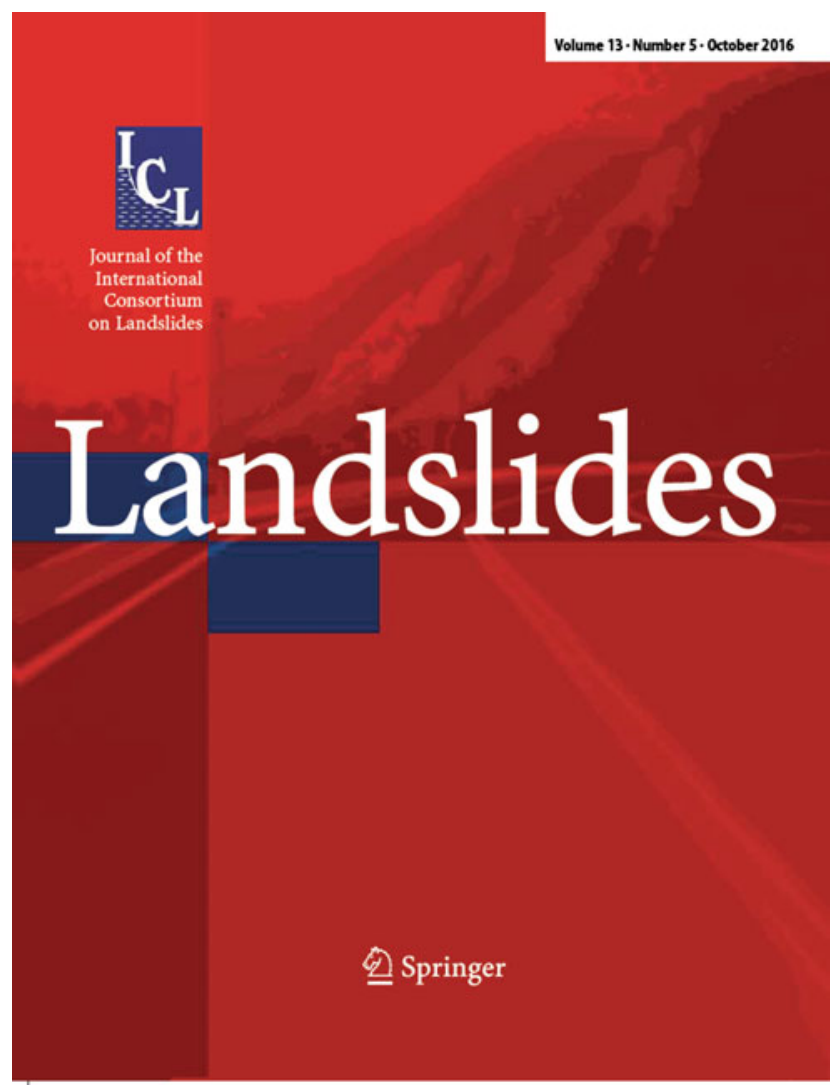

Fig. 1 The cover of Landslides: Journal of the International Consortium on Landslides

3.049 for 2015 and the ranking No. 1 in geological engineering journals.

The achievements of Landslides from 2004 to 2009 were presented by Sassa et al. (2009) and from 2009 to 2013 by Sassa et al. (2013) in Landslides. In this paper we will present some achievements of Landslides from the first issue in April 2004 until the writing of this manuscript at the end of September 2016, based on data from Thomson Reuters (Institute for Scientific Information) and publisher Springer Nature.

\section{Impact of the Landslides Journal}

\section{Impact Factor}

One of the most widely accepted impact indexes of a publication to the society is Impact Factor (IF), which is annually reported by Thomson Reuters (Institute for Scientific Information, ISI). The Impact Factor is calculated by dividing the number of current year citations in ISI databases to the source items published in that journal during the previous two years. The IF value is reflected by 
authors/scientists of published papers, not always by the practitioners/users of published papers.

The Impact Factor of Landslides after its first release in 2008 has shown an almost continuous rise, especially in the last three years, from 0.986 to 3.049 in 2015 . The Impact Factor and related data necessary for Impact Factor calculation from 2008 to 2015 are presented in Table 1. There is also a clearly visible rise of citable articles in 2013, when started bimonthly publication of the Landslides journal with 100 pages per issue (Vol. 10, Issues No. 1-4) and 150 pages per issue (Vol. 10. Issues No. 4-5), and again in 2014 when increased the size to 200 pages per issue (from Vol. 11 Issue No.3). The consequence of the rise of published citable articles is also an increasing citation of published articles of $40 \%$ in $2013,23 \%$ in 2014 and $40 \%$ in 2015 .

\section{Citations}

Impact Factors are calculated based on the number of citations of each article published in a journal during the previous two years, or five years for the five-year Impact Factor. The most cited articles published in Landslides journal, especially in years following the publication of an article, are the most important for a value of the Impact Factor. The five-year Impact Factor indicates the general quality of published articles and it is more appropriate for journals in certain fields such as landslides, because the body of citations may not be large enough to make reasonable comparisons, publication schedules may be consistently late, or it may take longer than two years to disseminate and respond to published works. Table 2. presents the 10 most cited manuscripts published in Landslides to the end of 2015 according to Institute for Scientific Information, ISI.

The most cited article is "The rainfall intensity-duration control of shallow landslides and debris flows: an update" prepared by Fausto Guzzetti, Silvia Peruccacci, Mauro Rossi and Colin P. Stark; Landslides Vol. 5. Issue No. 1 (2008) with 256 citations.

\section{The Journal Impact}

The influence and impact of a journal in the world of science is quantifiable according to positon of the journal in the Thompson Reuters Journal Citation Reports ${ }^{\circledR}$ related to the achieved Impact Factor. Thompson Reuters Journal Citation Reports ${ }^{\circledR}$ offers a systematic, objective means to critically evaluate the world's leading journals, with quantifiable, statistical information based on citation data. By compiling articles' cited references, JCR helps to measure research influence and impact at the journal and category levels, and shows the relationship between citing and cited journals (http://ipscience. thomsonreuters.com/product/journal-citation-reports).

Landslides journal, according to the Thompson Reuters Journal Citation Reports ${ }^{\circledR}$, is ranked at the top of 35 journals in the category Engineering, Geological (1/35) and 32nd of 184 journals in category of Geosciences, Multidisciplinary (32/184) (see Table 3) (http://ipscience.thomsonreuters.com/ product/journal-citation-reports).

The category Engineering, Geological, according to the Thompson Reuters Journal Citation Reports ${ }^{\circledR}$, includes multidisciplinary resources that encompass the knowledge and experience drawn from both geosciences and various engineering disciplines (primarily civil engineering). Resources in this category cover geotechnical engineering, geotechnics, geotechnology, soil dynamics, earthquake engineering, geotextiles and geomembranes, engineering geology and rock mechanics. The much wider category Geosciences, Multidisciplinary covers resources having a general or interdisciplinary approach to the study of the Earth and other planets. Relevant topics include geology, geochemistry/geophysics, hydrology, paleontology, oceanography, meteorology, mineralogy, geography, and energy and fuels. Resources having a primary focus on geology, or geochemistry and geophysics are placed in their own categories (http://ip-science.thomsonreuters.com/mjl/ scope/scope_scie).

Landslides journal has been on the top of the list of journals in the category Engineering, Geological continuously for the
Table 1 Impact factor, 5-year impact factor, number of total citable articles, total cites and cites per volume

\begin{tabular}{|l|l|l|l|l|l|}
\hline Year & $\begin{array}{l}\text { Impact } \\
\text { factor }\end{array}$ & $\begin{array}{l}\text { 5-year Impact } \\
\text { factor }\end{array}$ & $\begin{array}{l}\text { Total citable } \\
\text { articles }\end{array}$ & $\begin{array}{l}\text { Total } \\
\text { cites }\end{array}$ & $\begin{array}{l}\text { Cites per } \\
\text { volume }\end{array}$ \\
\hline 2015 & 3.049 & 3.616 & 90 & 1839 & 35 \\
\hline 2014 & 2.870 & 3.205 & 85 & 1310 & 139 \\
\hline 2013 & 2.814 & 3.045 & 59 & 1067 & 228 \\
\hline 2012 & 2.093 & 2.358 & 41 & 760 & 243 \\
\hline 2011 & 2.216 & 1.841 & 45 & 535 & 190 \\
\hline 2010 & 1.625 & 1.938 & 41 & 461 & 223 \\
\hline 2009 & 1.703 & 2.374 & 33 & 460 & 213 \\
\hline 2008 & 0.754 & N/A & 39 & 231 & 202 \\
\hline 2007 & 0.986 & N/A & 35 & 155 & 182 \\
\hline
\end{tabular}


Table 2 Ten most cited manuscript published in

Landslides to the end of 2015

according to Institute for

Scientific Information, ISI

\begin{tabular}{|c|c|c|c|c|c|c|}
\hline No & Article title & Authors & Vol & No & Year & Citations \\
\hline 1 & $\begin{array}{l}\text { The rainfall intensity-duration control of } \\
\text { shallow landslides and debris flows: an } \\
\text { update }\end{array}$ & $\begin{array}{l}\text { Fausto } \\
\text { Guzzetti } \\
\text { et al. }\end{array}$ & 5 & 1 & 2008 & 256 \\
\hline 2 & $\begin{array}{l}\text { Landslide hazard mapping at Selangor, } \\
\text { Malaysia using frequency ratio and logistic } \\
\text { regression models }\end{array}$ & $\begin{array}{l}\text { Saro Lee } \\
\text { and } \\
\text { Biswajeet } \\
\text { Pradhan }\end{array}$ & 4 & 1 & 2007 & 212 \\
\hline 3 & $\begin{array}{l}\text { Landslide hazards triggered by the } 2008 \\
\text { Wenchuan earthquake, Sichuan, China }\end{array}$ & $\begin{array}{l}\text { Yueping } \\
\text { Yin et al. }\end{array}$ & 6 & 2 & 2009 & 147 \\
\hline 4 & $\begin{array}{l}\text { Landslide susceptibility mapping using } \\
\text { GIS-based weighted linear combination, } \\
\text { the case in Tsugawa area of Agano River, } \\
\text { Niigata Prefecture, Japan }\end{array}$ & $\begin{array}{l}\text { Lulseged } \\
\text { Yimam } \\
\text { Ayalew } \\
\text { et al. }\end{array}$ & 1 & 1 & 2004 & 146 \\
\hline 5 & $\begin{array}{l}\text { Regional landslide susceptibility analysis } \\
\text { using back-propagation neural network } \\
\text { model at Cameron Highland, Malaysia }\end{array}$ & $\begin{array}{l}\text { Biswajeet } \\
\text { Pradhan and } \\
\text { Saro Lee }\end{array}$ & 7 & 1 & 2010 & 115 \\
\hline 6 & $\begin{array}{l}\text { An approach for GIS-based statistical } \\
\text { landslide susceptibility zonation - with a } \\
\text { case study in the Himalayas }\end{array}$ & $\begin{array}{l}\text { Ashis K. } \\
\text { Saha et al. }\end{array}$ & 2 & 1 & 2005 & 113 \\
\hline 7 & Global landslide and avalanche hotspots & $\begin{array}{l}\text { Farrokh } \\
\text { Nadim et al. }\end{array}$ & 3 & 2 & 2006 & 108 \\
\hline 8 & $\begin{array}{l}\text { The } 12 \text { May Wenchuan } \\
\text { earthquake-induced landslide lakes: } \\
\text { distribution and preliminary risk evaluation }\end{array}$ & $\begin{array}{l}\text { Peng Cui } \\
\text { et al. }\end{array}$ & 6 & 3 & 2009 & 95 \\
\hline 9 & $\begin{array}{l}\text { Survey and monitoring of landslide } \\
\text { displacements by means of L-band satellite } \\
\text { SAR interferometry }\end{array}$ & $\begin{array}{l}\text { Tazio } \\
\text { Strozzi et al. }\end{array}$ & 2 & 3 & 2005 & 93 \\
\hline 10 & $\begin{array}{l}\text { The Varnes classification of landslide } \\
\text { types, an update }\end{array}$ & $\begin{array}{l}\text { Oldrich } \\
\text { Hungr et al. }\end{array}$ & 9 & 1 & 2014 & 88 \\
\hline
\end{tabular}

Table 3 Thompson Reuters Journal Citation Reports ${ }^{\circledR}$ ranking of Landslides in the period 2007 2015

\begin{tabular}{|l|l|l|l|l|}
\hline & \multicolumn{2}{|l|}{ Engineering, geological } & \multicolumn{2}{l}{ Geosciences, multidisciplinary } \\
\cline { 2 - 4 } & Rank & Quartile & Rank & Quartile \\
\hline 2015 & $1 / 35$ & Q1 & $32 / 184$ & Q1 \\
\hline 2014 & $1 / 32$ & Q1 & $30 / 175$ & Q1 \\
\hline 2013 & $1 / 33$ & Q1 & $31 / 174$ & Q1 \\
\hline 2012 & $2 / 32$ & Q1 & $56 / 172$ & Q2 \\
\hline 2011 & $1 / 30$ & Q1 & $38 / 170$ & Q1 \\
\hline 2010 & $5 / 30$ & Q1 & $65 / 167$ & Q2 \\
\hline 2009 & $3 / 27$ & Q1 & $51 / 155$ & Q2 \\
\hline 2008 & $12 / 25$ & Q2 & $109 / 144$ & Q4 \\
\hline 2007 & $6 / 26$ & Q1 & $76 / 137$ & Q3 \\
\hline
\end{tabular}

last three years and the difference in Impact Factor between the Landslides and the second ranked Acta Geotechnica is more than 0.6. The top 20 journals, their Impact Factors and total cites in 2015 in the category Engineering, Geological are listed in Table 4. In the much wider category Geosciences, Multidisciplinary, Landslides journal is ranked as 32nd after Journal of Glaciology (IF2015 = 3.109) and before Journal of Hydrology (IF2015 = 3.043) and Geomorphology
$(\mathrm{IF} 2015=2.813) \quad($ https://jcr.incites.thomsonreuters.com/ JCRJournalHomeAction). It is important that Landslides journal has ranked in quartile Q1 for the last three years in the category Geosciences, Multidisciplinary because the position in quartile Q1 is another indicator of the quality and influence of a journal, especially in Europe. In the category Engineering, Geological the Landslides journal has been continuously in quartile Q1 from 2007, except 2008. 
Table 4 Top 20 journals ranked by Impact Factor in the category Engineering, Geological in 2015 (http://ipscience.thomsonreuters. com/product/journal-citationreports)

\begin{tabular}{|c|c|c|c|c|}
\hline Rank & Journal title & Publisher & $\begin{array}{l}\text { IF } \\
2015\end{array}$ & $\begin{array}{l}\text { Total } \\
\text { cites }\end{array}$ \\
\hline 1 & Landslides & Springer Heidelberg & 3.049 & 1839 \\
\hline 2 & Acta Geotechnica & Springer Heidelberg & 2.426 & 649 \\
\hline 3 & Rock Mechanics and Rock Engineering & Springer Vienna & 2.386 & 2487 \\
\hline 4 & Geotextiles and Geomembranes & Elsevier Science BV & 2.366 & 1851 \\
\hline 5 & Earthquake Spectra & $\begin{array}{l}\text { Earthquake Engineering } \\
\text { Research Inst }\end{array}$ & 2.298 & 3068 \\
\hline 6 & Engineering Geology & Elsevier Science BV & 2.196 & 7398 \\
\hline 7 & $\begin{array}{l}\text { Earthquake Engineering and Structural } \\
\text { Dynamics }\end{array}$ & Wiley-Blackwell & 2.127 & 6379 \\
\hline 8 & Geosynthetics International & ICE Publishing & 2.066 & 725 \\
\hline 9 & Bulletin of Earthquake Engineering & Springer & 2.036 & 1468 \\
\hline 10 & $\begin{array}{l}\text { International Journal of Rock Mechanics } \\
\text { and Mining Sciences }\end{array}$ & $\begin{array}{l}\text { Pergamon-Elsevier Science } \\
\text { Ltd }\end{array}$ & 2.010 & 9728 \\
\hline 11 & Geotechnique & ICE Publishing & 2.000 & 7384 \\
\hline 12 & Canadian Geotechnical Journal & $\begin{array}{l}\text { Canadian Science } \\
\text { Publishing, NRC Research } \\
\text { Press }\end{array}$ & 1.877 & 6107 \\
\hline 13 & $\begin{array}{l}\text { International Journal for Numerical and } \\
\text { Analytical Methods in Geotechnics }\end{array}$ & Wiley-Blackwell & 1.758 & 3261 \\
\hline 14 & Computers and Geotechnics & Elsevier Science BV & 1.705 & 3067 \\
\hline 15 & $\begin{array}{l}\text { Journal of Geotechnical and } \\
\text { Geoenvironmental Engineering }\end{array}$ & $\begin{array}{l}\text { ASCE-Amer Soc Civil } \\
\text { Engineers }\end{array}$ & 1.696 & 6304 \\
\hline 16 & $\begin{array}{l}\text { Soil Dynamics and Earthquake } \\
\text { Engineering }\end{array}$ & Elsevier Science BV & 1.481 & 3663 \\
\hline 17 & International Journal of Geomechanics & $\begin{array}{l}\text { ASCE-Amer Soc Civil } \\
\text { Engineers }\end{array}$ & 1.387 & 994 \\
\hline 18 & $\begin{array}{l}\text { Bulletin of Engineering Geology and } \\
\text { Environment }\end{array}$ & Springer Heidelberg & 1.252 & 1237 \\
\hline 19 & Soils and Foundation & Elsevier Science BV & 1.238 & 2492 \\
\hline 20 & Geomechanics and Engineering & Techno Press & 1.085 & 188 \\
\hline
\end{tabular}

\section{Publications}

The number of articles submitted and accepted for publication in the Landslides journal continuously increased from the first year of publishing until now. The Landslides journal started in 2004 as a three-monthly journal (four issues per volume) with approximately 100 pages per issue. An increased number of accepted articles accompanied a change from three to bi-monthly publication of the Landslides journal in 2013 with 100 pages per issue (Vol. 10, Issues No. 1-4). The further rise of accepted articles resulted from increasing the number of the pages per issue to 150 pages from Vol. 10. Issues No. 4-5 and to 200 pages per issue from Vol. 11 Issue No. 3 in 2014. A rise in the number of submitted articles followed the increasing Impact Factor and the number of accepted manuscripts in the second half of 2016 indicates a necessary new increase in printed pages per issue.

\section{Categories of Articles}

Landslides published four major categories of articles:

- Original Papers (6-12 pages): original research and investigation results;

- Technical Note (less than 6 pages): research notes, review notes, case studies, progress of technology, and best practices;

- Recent Landslides (generally less than 6 pages): reports of recent landslides, including location (latitude/longitude), plan, section, geology, volume, movement, mechanism, and disasters within the available extent; in monitoring, testing, investigation, and mitigation measures; and

- International Consortium on Landslides (ICL)/International Programme on Landslides (IPL) Activities (length depending on the content): progress of IPL projects and ICL Committee activities. 
The categories of Original paper and Technical note are the same as in other scientific journals. The category of Recent Landslides is unique to Landslides and carries on the tradition begun by the Landslide News (1987-2003), an international newsletter published by the Japan Landslide Society (Sassa et al. 2009, 2015). The International Consortium on Landslides aims to contribute to the United Nations International Strategy for Disaster Reduction through developing landslide sciences, technology, and capacity building, and strengthening global cooperation for landslide risk reduction within developed and developing countries. The ICL established the International Programme on Landslides (IPL), together with ICL supporting organizations (UNESCO, UNISDR, WMO, FAO, UNU, ICSU,
WFEO, and IUGS). These activities are reported in ICL/IPL Activities (Sassa et al. 2015).

\section{Classification of Articles}

The submission of a manuscript to the Landslides journal should be only electronic through the Landslides Editorial Manager (EM) managed by Springer Nature. When an article needs to be submitted through the Landslides Editorial Manager, the author is requested to classify the manuscript based on a list of article classifications (see Table 5). Starting from Vol. 10 (2013), the current article classification has four major classes: Background Science,

Table 5 Classification of articles

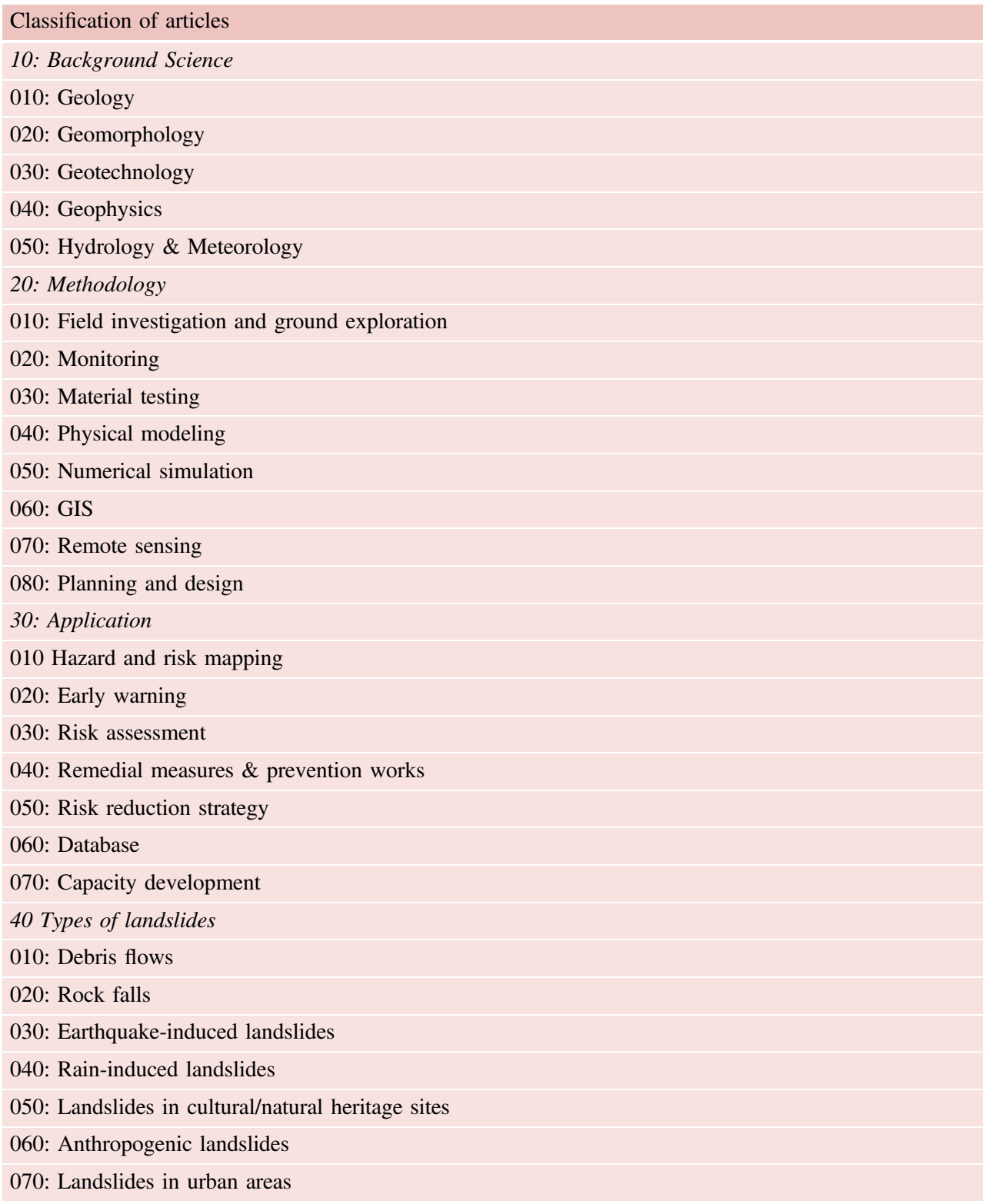


Table 6 Editorial status summary 2013-2015 (Schwarz and Mannsperger 2016)

\begin{tabular}{|l|l|l|l|}
\hline Submissions & 2013 & 2014 & 2015 \\
\hline Total Submitted & 189 & 242 & 301 \\
\hline Total Decisions & 188 & 208 & 279 \\
\hline Accept & 76 & 87 & 117 \\
\hline Reject & 112 & 121 & 162 \\
\hline Acceptance Rate (\%) & 40 & 42 & 42 \\
\hline Rejection Rate (\%) & 60 & 58 & 58 \\
\hline Average Days to First Decision & 65 & 79 & 49 \\
\hline Average Days to Final Disposition Accept & 228 & 214 & 205 \\
\hline Average Days to Final Disposition Reject & 59 & 76 & 68 \\
\hline
\end{tabular}

Methodology, Application and Types of Landslides. An author can chose one or more classes for the submitted manuscript.

\section{Editorial Process}

Each article submitted to the Landslides journal should be uploaded in the Editorial Manger (EM) as a New assignment article. New assignment articles are passed to Executive Editors, who are requested to upload their opinions of whether the article should be passed to in-depth review or rejected without in-depth review, and whether contributed category and page length are appropriate or not.

Executive Editors organize editorial meetings every week by Skype and decide the assignment of a handling Editor for each article passed for in-depth review. The handling Editors are assigned from a database of around 100 registered Editors in Editorial Manager (EM), identifying classifications attached to their research area. The handling Editor will assign one or two Reviewers, depending on the article's category, from the database of around 950 registered Reviewers in Editorial Manager, with their personal classifications. Reviewers are searched by classification matching. The handling Editor's recommendation, based on results of conducted reviews for each article, will be uploaded to EM. The Editor-in-Chief will then make a final decision, mostly following the handling Editor's recommendations. During the peer review process, submitted manuscripts go through one or more revision stages leading up to final acceptance or rejection. The editorial status summary is presented in Table 6 (Schwarz and Mannsperger 2016). The table summarizes the activity for the journal office between January 1st and December 31st of each year, but Only "Original Submissions" have been taken into account. From Table 6 it is clearly visible that there has been a continuous rise in submitted manuscripts and also that the acceptance and rejection rates have been almost identical during the last three years (and before). The rejection rate for a year is calculated as the number of rejected manuscripts this year compared to the total number of decisions in the year, which is defined here as the number of rejected manuscripts plus the number of accepted manuscripts. The term Reject is used for the calculation of the acceptance and rejection rates, which includes all terms that may exist for rejection decisions: Reject before review; Reject after review; Reject, but resubmit; Reject, out of scope; and so forth. Only the papers for which the Final Disposition Date has been set are taken into account. Final disposition date means that a manuscript is fully completed (Schwarz and Mannsperger 2016).

One of important tasks for the Editorial Board is to reduce the peer review process to enable publishing of an article as soon as possible. The longest period from submission to the final decision was a maximum of around one year. The

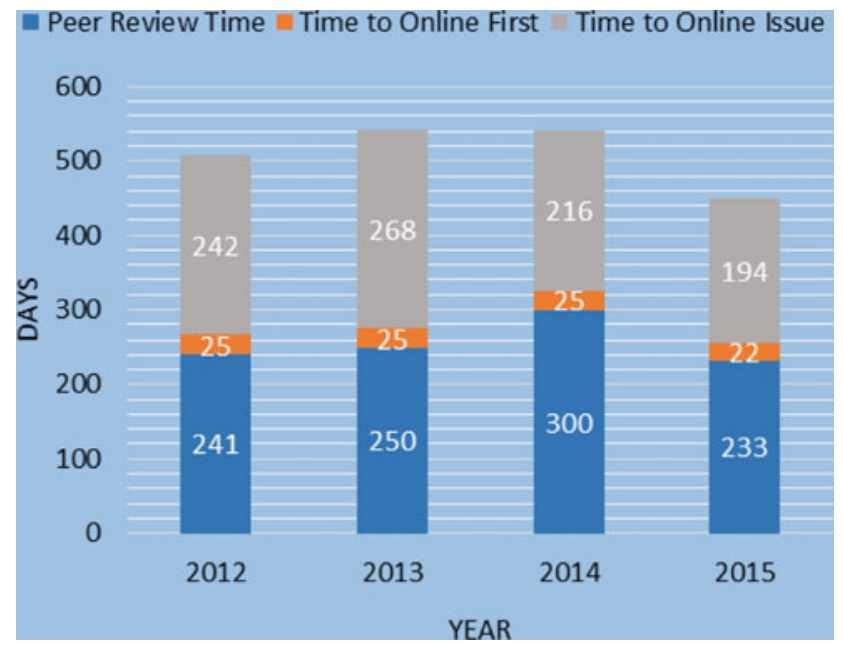

Fig. 2 Average time between submission of a manuscript and publication in an Online Issue 2013-2015 (Schwarz and Mannsperger 2016) 
Editorial Board is making efforts to reduce this period to 6 months. The average time between submission of the article and publication is presented in Fig. 2 (Schwarz and Mannsperger 2016).

It is clear in Fig. 1 that peer review time has decreased continuously during the last three years, but the time for publishing an article after Springer's Online First ${ }^{\circledR}$ is very long, although this period is becoming shorter.

The publication of accepted articles via Springer's Online First ${ }^{\circledR}$ is very important and enables internet readers to view the article soon after final acceptance. Articles published via Springer's Online First ${ }^{\circledR}$ service are final articles published online after an author has reviewed proofs and all corrections have been carried out. Metadata is sent to all relevant bibliographic services for inclusion in abstracting and indexing databases immediately after online publication. Articles are published on the SpringerLink platform in PDF format and only final pagination and the citation line are later added in the printed version. Articles are fully citable by their DOI (Digital Object Identifier) and the official publication date is the online publication date. Publication of papers through Springer's Online First ${ }^{\circledR}$ helps shorten the time between publication and citation (Schwarz and Mannsperger 2016).

\section{Article Downloading}

While accepted articles are available to the readers after publishing via Springer's Online First ${ }^{\circledR}$ service, article downloading is an important way for disseminating article results. The downloading of Landslides articles is rapidly increasing in last three years, which also indicates the high quality of the accepted and published articles (Fig. 3).
The top 10 most downloaded Landslides' articles in 2015, according to Institute for Scientific Information, ISI, are listed in Table 7.

\section{Landslides' Best Paper Award}

The Best Paper Award for the best paper published in Landslides: Journal of the International Consortium on Landslide has been given annually, beginning with the year 2004 for the first volume (Vol. 1) of the journal. The selection of the Best Paper Award is carried out by the Best Paper Award Subcommittee. The judging and ranking of papers were based on a numerical grading system that involved three elements in the final score of the paper: (i) Scientific and technical quality of the paper (up to 50\%), (ii) Impact on the profession and society (up to 30\%), and (iii) Quality of figures and tables (up to 20\%). The proposal of Best Paper Award should be approved by the Board of Representatives of the International Consortium on Landslides. The Landslides Best Paper Awards from the Vol. 1 to Vol. 12 are listed in Table 8.

Acknowledgements Landslides' Editorial Board deeply appreciate the work of all Editors and Reviewers, for their voluntary contributions to editing and reviewing articles submitted to the Landslides journal. In the last 5 years, the number of articles submitted and published in Landslides has increased more than three times from 100 pages per issue and 4 issues per year to 200 pages per issue and 6 issues per year and is still increasing, and may result in more pages per issue and/or possible monthly publication of Landslides. These circumstances would increase the editorial work for Landslides' Editors and Reviewers. The main goals of the Landslides Editorial Board, Editors, Reviewers and all others included in the editorial process are further improvements of manuscript quality, speeding-up of the peer review process and faster publication of landslide science achievements to enable all types of Landslides' readers quick access to new knowledge in landslide science.

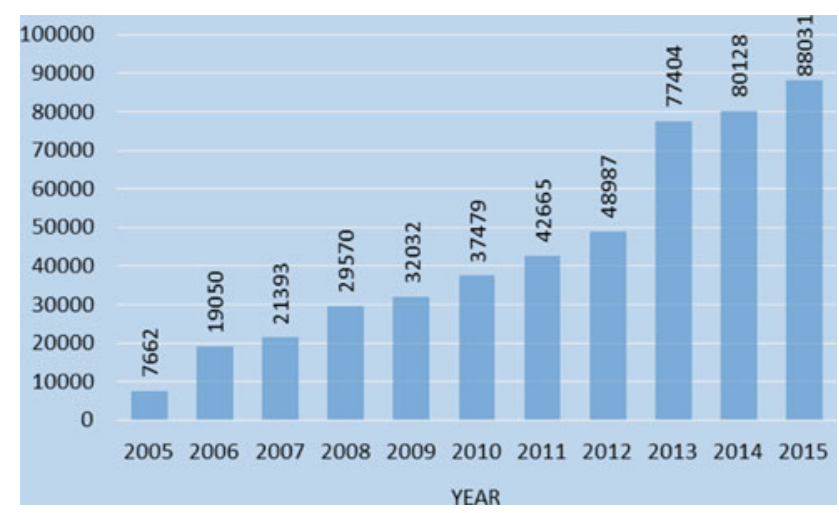

Fig. 3 Downloads of Landslides articles 2012-2015 (Schwarz and Mannsperger 2016) 
Table 7 Top 10 most downloaded Landslides articles in 2015 according to Institute for Scientific Information, ISI

\begin{tabular}{|c|c|c|c|c|c|c|}
\hline Rank & Article Title & Authors & Vol & No & Year & Download \\
\hline 1 & $\begin{array}{l}\text { The Varnes classification of landslide } \\
\text { types, an update }\end{array}$ & $\begin{array}{l}\text { Oldrich Hungr } \\
\text { et al. }\end{array}$ & 11 & 2 & 2014 & 2053 \\
\hline 2 & $\begin{array}{l}\text { Landslide susceptibility mapping } \\
\text { using multi-criteria evaluation } \\
\text { techniques in Chittagong } \\
\text { Metropolitan Area, Bangladesh }\end{array}$ & Bayes Ahmed & 12 & 6 & 2015 & 1131 \\
\hline 3 & $\begin{array}{l}\text { The rainfall intensity-duration } \\
\text { control of shallow landslides and } \\
\text { debris flows: an update }\end{array}$ & $\begin{array}{l}\text { Fausto } \\
\text { Guzzetti et al. }\end{array}$ & 5 & 1 & 2008 & 1030 \\
\hline 4 & $\begin{array}{l}\text { Three (nearly) complete inventories } \\
\text { of landslides triggered by the May } 12 \text {, } \\
2008 \text { Wenchuan Mw } 7.9 \text { earthquake } \\
\text { of China and their spatial distribution } \\
\text { statistical analysis }\end{array}$ & $\begin{array}{l}\text { Chong Xu } \\
\text { et al. }\end{array}$ & 11 & 3 & 2014 & 694 \\
\hline 5 & $\begin{array}{l}\text { Landslide hazards triggered by the } \\
2008 \text { Wenchuan Earthquake, } \\
\text { Sichuan, China }\end{array}$ & $\begin{array}{l}\text { Yueping Yin } \\
\text { et al. }\end{array}$ & 6 & 2 & 2009 & 634 \\
\hline 6 & $\begin{array}{l}\text { Landslide susceptibility mapping } \\
\text { using GIS-based multi-criteria } \\
\text { decision analysis, support vector } \\
\text { machines, and logistic regression }\end{array}$ & $\begin{array}{l}\text { Taskin } \\
\text { Kavzoglu } \\
\text { et al. }\end{array}$ & 11 & 3 & 2014 & 630 \\
\hline 7 & $\begin{array}{l}\text { Generation of a Landslide Risk Index } \\
\text { Map for Cuba using spatial } \\
\text { multi-criteria evaluation }\end{array}$ & $\begin{array}{l}\text { Enrique } \\
\text { Armando } \\
\text { Castellanos } \\
\text { Abella et al. }\end{array}$ & 4 & 4 & 2007 & 590 \\
\hline 8 & $\begin{array}{l}\text { New insights into the temporal } \\
\text { prediction of landslides by a } \\
\text { terrestrial SAR interferometry } \\
\text { monitoring case study }\end{array}$ & $\begin{array}{l}\text { Paolo } \\
\text { Mazzanti et al. }\end{array}$ & 12 & 1 & 2015 & 536 \\
\hline 9 & $\begin{array}{l}\text { Spatial prediction models for shallow } \\
\text { landslide hazards: a comparative } \\
\text { assessment of the efficacy of support } \\
\text { vector machines, artificial neural } \\
\text { networks, kernel logistic regression, } \\
\text { and logistic model tree }\end{array}$ & Dieu Tien Bui & 13 & 2 & 2016 & 528 \\
\hline 10 & $\begin{array}{l}\text { Integration of rainfall thresholds and } \\
\text { susceptibility maps in the Emilia } \\
\text { Romagna (Italy) regional-scale } \\
\text { landslide warning system }\end{array}$ & $\begin{array}{l}\text { Samuele } \\
\text { Segoni et al. }\end{array}$ & 12 & 4 & 2015 & 491 \\
\hline
\end{tabular}


Table 8 The Landslides best paper awards from the Vol. 1 to Vol. 12 (2004-2015)

\begin{tabular}{|c|c|c|c|c|}
\hline Authors & Article Title & Vol. & No & Year \\
\hline Margottini C. & $\begin{array}{l}\text { Instability and geotechnical problems } \\
\text { of the Buddha niches and surrounding } \\
\text { cliff in Bamiyan Valley, central } \\
\text { Afghanistan }\end{array}$ & 1 & 5 & 2004 \\
\hline $\begin{array}{l}\text { Baum R.L., Coe J.A., Godt J.W., } \\
\text { Harp E.L., Reid M.E., Savage W.Z., } \\
\text { Schulz W.H., Brien D.L., } \\
\text { Chleborad A.F., McKenna J.P. and } \\
\text { Michael J.A. }\end{array}$ & $\begin{array}{l}\text { Regional landslide-hazard assessment } \\
\text { for Seattle, Washington, USA }\end{array}$ & 2 & 4 & 2005 \\
\hline $\begin{array}{l}\text { Nadim F., Kjekstad O., Peduzzi P., } \\
\text { Herold C., and Jaedicke C. }\end{array}$ & $\begin{array}{l}\text { Global landslide and avalanche } \\
\text { hotspots }\end{array}$ & 3 & 2 & 2006 \\
\hline $\begin{array}{l}\text { Leynaud D., Sultan N., and } \\
\text { Mienert J. }\end{array}$ & $\begin{array}{l}\text { The role of sedimentation rate and } \\
\text { permeability in the slope stability of the } \\
\text { formerly glaciated Norwegian } \\
\text { continental margin: the Storegga slide } \\
\text { model }\end{array}$ & 4 & 4 & 2007 \\
\hline $\begin{array}{l}\text { Prochaska A.B., Santi P.M., } \\
\text { Higgins J.D., and Cannon S.H. }\end{array}$ & $\begin{array}{l}\text { A study of methods to estimate debris } \\
\text { flow velocity }\end{array}$ & 5 & 4 & 2008 \\
\hline $\begin{array}{l}\text { Lundström K., Larsson R., and } \\
\text { Dahlin T. }\end{array}$ & $\begin{array}{l}\text { Mapping of quick clay formations } \\
\text { using geotechnical and geophysical } \\
\text { methods }\end{array}$ & 6 & 1 & 2009 \\
\hline $\begin{array}{l}\text { Massey C.I., Manville V., } \\
\text { Hancox G.H., Keys H.J., } \\
\text { Lawrence C., and McSaveney M. }\end{array}$ & $\begin{array}{l}\text { Out-burst flood (lahar) triggered by } \\
\text { retrogressive landsliding, } 18 \text { March } \\
2007 \text { at Mt Ruapehu,New Zealand-a } \\
\text { successful early warning }\end{array}$ & 7 & 3 & 2010 \\
\hline $\begin{array}{l}\text { Brideau M.A., Pedrazzini A., } \\
\text { Stead D., Froese C., Jaboyedoff M. } \\
\text { and van Zeyl D. }\end{array}$ & $\begin{array}{l}\text { Three-dimensional slope stability } \\
\text { analysis of South Peak, Crowsnest } \\
\text { Pass, Alberta, Canada }\end{array}$ & 8 & 2 & 2011 \\
\hline $\begin{array}{l}\text { Pinyol N.M., Alonso E.E., } \\
\text { Corominas J. and Moya J. }\end{array}$ & $\begin{array}{l}\text { Canelles landslide: modelling rapid } \\
\text { drawdown and fast potential sliding }\end{array}$ & 9 & 1 & 2012 \\
\hline Sosio R., Crosta G.B. and Hungr, O. & $\begin{array}{l}\text { Numerical modeling of debris } \\
\text { avalanche propagation from collapse of } \\
\text { volcanic edifices }\end{array}$ & 9 & 3 & 2012 \\
\hline $\begin{array}{l}\text { Staley D.M., Kean J.W., Cannon S. } \\
\text { H., Schmidt K.M. and Laber J.L. }\end{array}$ & $\begin{array}{l}\text { Objective definition of rainfall intensity } \\
\text { - duration thresholds for the initiation } \\
\text { of post-fire debris flows in southern } \\
\text { California }\end{array}$ & 10 & 5 & 2013 \\
\hline $\begin{array}{l}\text { Hungr O., Leroueil S. and } \\
\text { Picarelli L. }\end{array}$ & $\begin{array}{l}\text { The Varnes classification of landslide } \\
\text { types, an update }\end{array}$ & 11 & 2 & 2014 \\
\hline $\begin{array}{l}\text { Huang D., Cen D., Ma G., and } \\
\text { Huang R. }\end{array}$ & $\begin{array}{l}\text { Step-path failure of rock slopes with } \\
\text { intermittent joints }\end{array}$ & 12 & 5 & 2015 \\
\hline
\end{tabular}

\section{References}

Abella EAC, van Westen CV (2007) Generation of a landslide risk index map for Cuba using spatial multi-criteria evaluation. Landslides 4(4):311-325

Ahmed B (2015) Landslide susceptibility mapping using multi-criteria evaluation techniques in Chittagong metropolitan area, Bangladesh. Landslides 12(6):1077-1095

Ayalew LY, Yamagishi H, Ugawa N (2004) Landslide susceptibility mapping using GIS-based weighted linear combination, the case in Tsugawa area of Agano River, Niigata Prefecture, Japan. Landslides 1(1):73-81
Baum RL, Coe JA, Godt JW, Harp EL, Reid ME, Savage WZ, Schulz WH, Brien DL, Chleborad AF, McKenna JP, Michael JA (2005) Regional landslide-hazard assessment for Seattle, Washington, USA. Landslides 2(4):266-279

Brideau MA, Pedrazzini A, Stead D, Froese C, Jaboyedoff M, Zeyl D (2011) Three-dimensional slope stability analysis of South Peak, Crowsnest Pass, Alberta, Canada. Landslides 8(2):139-158

Cui P, Zhu Y, Han Y, Chen X, Zhuang J (2009) The 12 May Wenchuan earthquake-induced landslide lakes: distribution and preliminary risk evaluation. Landslides 6(3):209-233

Guzzetti F, Peruccacci S, Rossi M, Stark CP (2008) The rainfall intensity-duration control of shallow landslides and debris flows: an update. Landslides 5(1):3-17 
Huang D, Cen D, Ma G, Huang R (2015) Step-path failure of rock slopes with intermittent joints. Landslides 12(5):911-926

Hungr O, Leroueil S, Picarelli L (2014) The Varnes classification of landslide types, an update. Landslides 11(2):167-194

Kavzoglu T, Sahin EK, Colkesen I (2014) Landslide susceptibility mapping using GIS-based multi-criteria decision analysis, support vector machines, and logistic regression. Landslides 11(3):425-439

Lee S, Pradhan B (2007) Landslide hazard mapping at Selangor, Malaysia using frequency ratio and logistic regression models. Landslides 4(1):33-41

Leynaud D, Sultan N, Mienert J (2007) The role of sedimentation rate and permeability in the slope stability of the formerly glaciated Norwegian continental margin: the Storegga slide model. Landslides 4(4):297-309

Lundström K, Larsson R, Dahlin T (2009) Mapping of quick clay formations using geotechnical and geophysical methods. Landslides $6(1): 1-15$

Margottini C (2004) Instability and geotechnical problems of the Buddha niches and surrounding cliff in Bamiyan Valley, central Afghanistan. Landslides 1(1):41-51

Massey CI, Manville V, Hancox GH, Keys H, Lawrence C, McSaveney M (2010) Out-burst flood (lahar) triggered by retrogressive landsliding, 18 March 2007 at Mt Ruapehu, New Zealand - a successful early warning. Landslides 7(3):303-315

Mazzanti P, Bozzano F, Cipriani I, Prestininzi A (2015) New insights into the temporal prediction of landslides by a terrestrial SAR interferometry monitoring case study. Landslides 12(1):55-68

Nadim F, Kjekstad O, Peduzzi P, Herold C, Jaedicke C (2006) Global landslide and avalanche hotspots. Landslides 3(2):159-173

Pinyol NM, Alonso EE, Corominas J, Moya J (2012) Canelles landslide: modelling rapid drawdown and fast potential sliding. Landslides 9(1):33-51

Pradhan B, Lee S (2010) Regional landslide susceptibility analysis using backpropagation neural network model at Cameron Highland, Malaysia. Landslides 7(1):13-30

Prochaska AB, Santi PM, Higgins JD, Cannon SH (2008) A study of methods to estimate debris flow velocity. Landslides 5(4):413-444

Saha AK, Gupta RP, Sarkar I, Arora MK, Csaplovics E (2005) An approach for GIS-based statistical landslide susceptibility zonation-with a case study in the Himalayas. Landslides 2(1):61-69
Sassa K (2004) The international programme on landslides (IPL). Landslides 1:95-99

Sassa K (2006) "2006 Tokyo Action Plan"-strengthening research and learning on landslides and related earth system disasters for global risk preparedness. Landslides 3:361-369

Sassa K, Tsuchiya S, Ugai K, Wakai A, Uchimura T (2009) Landslides: a review of achievements in the first 5 years (2004-2009). Landslides 6(4):275-286

Sassa K, Tsuchiya S, Fukuoka H, Mikoš M, Doan L (2015) Landslides: review of achievements in the second 5-year period (2009-2013). Landslides 12(2):213-223

Schwarz J, Mannsperger C (2016) Landslides-2015 Publisher's Report. Springer Nature, Heidelberg. 48p

Segoni S, Lagomarsino D, Fanti R, Moretti S, Casagli N (2015) Integration of rainfall thresholds and susceptibility maps in the Emilia Romagna (Italy) regional-scale landslide warning system. Landslides 12(4):773-785

Sosio R, Crosta GB, Hungr O (2012) Numerical modeling of debris avalanche propagation from collapse of volcanic edifices. Landslides 9(3):315-334

Staley DM, Kean JW, Cannon SH, Schmidt KM, Laber JL (2013) Objective definition of rainfall intensity-duration thresholds for the initiation of post-fire debris flows in southern California. Landslides 10(5):547-562

Strozzi T, Farina P, Corsini A, Ambrosi C, Thüring M, Zilger J, Wiesmann A, Wegmüller U, Werner C (2005) Survey and monitoring of landslide displacements by means of L-band satellite SAR interferometry. Landslides 2(3):193-201

Tien Bui D, Tuan T, Klempe H, Pradhan B, Revhaug I (2016) Spatial prediction models for shallow landslide hazards: a comparative assessment of the efficacy of support vector machines, artificial neural networks, kernel logistic regression, and logistic model tree. Landslides 13(2):361-378

Xu C, Xu X, Yao X, Dai F (2014) Three (nearly) complete inventories of landslides triggered by the May 12, 2008 Wenchuan Mw 7.9 earthquake of China and their spatial distribution statistical analysis. Landslides 11(3):441-461

Yin Y, Wang F, Sun P (2009) Landslide hazards triggered by the 2008 Wenchuan Earthquake, Sichuan, China. Landslides 6(2):139-152
Open Access This chapter is licensed under the terms of the Creative Commons Attribution 4.0 International License (http:// creativecommons.org/licenses/by/4.0/), which permits use, sharing, adaptation, distribution and reproduction in any medium or format, as long as you give appropriate credit to the original author(s) and the source, provide a link to the Creative Commons license and indicate if changes were made.
The images or other third party material in this chapter are included in the chapter's Creative Commons license, unless indicated otherwise in a credit line to the material. If material is not included in the chapter's Creative Commons license and your intended use is not permitted by statutory regulation or exceeds the permitted use, you will need to obtain permission directly from the copyright holder. 